\title{
Enhancing wellbore cement integrity with microbially induced calcite precipitation (MICP): A field scale demonstration
}

\section{Authors: Adrienne J. Phillips, E. Troyer, R. Hiebert, Catherine M. Kirkland, Robin Gerlach, Alfred B. Cunningham, Lee H. Spangler, J. Kirksey, W. Rowe, and R. Esposito}

NOTICE: this is the author's version of a work that was accepted for publication in Journal of Petroleum Science and Engineering. Changes resulting from the publishing process, such as peer review, editing, corrections, structural formatting, and other quality control mechanisms may not be reflected in this document. Changes may have been made to this work since it was submitted for publication. A definitive version was subsequently published in Journal of Petroleum Science and Engineering, VOL\# 171, (December 2018)

DOI\#10.1016/j.petrol.2018.08.012.

Phillips, Adrienne J., E. Troyer, R. Hiebert, Catherine M. Kirkland, Robin Gerlach, Alfred B. Cunningham, Lee H. Spangler, J. Kirksey, W. Rowe, and R. Esposito. "Enhancing Wellbore Cement Integrity with Microbially Induced Calcite Precipitation (MICP): A Field Scale Demonstration." Journal of Petroleum Science and Engineering 171 (December 2018): 11411148. doi:10.1016/j.petrol.2018.08.012. 


\title{
Enhancing wellbore cement integrity with microbially induced calcite precipitation (MICP): A field scale demonstration
}

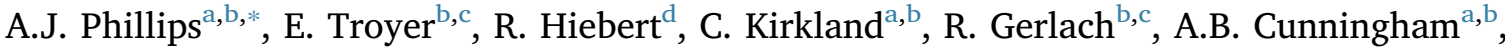 \\ L. Spangler ${ }^{\mathrm{e}}$, J. Kirksey ${ }^{\mathrm{f}}$, W. Rowe ${ }^{g}$, R. Esposito ${ }^{\mathrm{h}}$ \\ ${ }^{a}$ Department of Civil Engineering, Montana State University, Bozeman, MT, United States \\ ${ }^{\mathrm{b}}$ Center for Biofilm Engineering, Montana State University, Bozeman, MT, United States \\ ${ }^{c}$ Department of Chemical \& Biological Engineering, Montana State University, Bozeman, MT, United States \\ d Montana Emergent Technologies, Butte, MT, United States \\ e Energy Research Institute, Montana State University, Bozeman, MT, United States \\ ${ }^{\mathrm{f}}$ Loudon Technical Services, Charleston, WV, United States \\ ${ }^{\mathrm{S}}$ Schlumberger, Denver, CO, United States \\ ${ }^{\mathrm{h}}$ Southern Company, Birmingham, AL, United States
}

\begin{abstract}
A B S T R A C T
The presence of delaminations, apertures, fractures, voids and other unrestricted flow channels in the wellbore environment substantially reduces wellbore integrity. Compromised cement may cause a loss of zonal isolation leading to deleterious flow of fluids between zones or to the surface with multiple potential negative impacts including: loss of resource production, reduction of sweep efficiency in EOR operations, and regulatory noncompliance. One potential solution to enhance wellbore integrity is microbially induced calcite precipitation (MICP) to plug preferential flow pathways. MICP is promoted with micrometer-sized organisms and low viscosity (aqueous) solutions thereby facilitating fluid transport into small aperture, potentially tortuous leakage flow paths within the cement column. In this study, MICP treatment of compromised wellbore cement was demonstrated at a depth interval of 310.0-310.57 m (1017-1019 feet) below ground surface (bgs) using conventional oil field subsurface fluid delivery technologies (packer, tubing string, and a slickline deployed bailer). After 25 urea/calcium solution and 10 microbial (Sporosarcina pasteurii) suspension injections, injectivity was reduced from the initial 0.29 cubic meters per hour $\left(\mathrm{m}^{3} / \mathrm{h}\right)(1.28$ gallons per minute (gpm)) to less than $0.011 \mathrm{~m}^{3} / \mathrm{h}(0.05 \mathrm{gpm})$. The flow rate was decreased while maintaining surface pumping pressure below a maximum pressure of $81.6 \mathrm{bar}$ (1200 psi) to minimize the potential for fracturing a shale formation dominant in this interval. The pressure decay immediately after each injection ceased decreased after MICP treatment. Comparison of pre- and post-test cement evaluation logs revealed substantial deposition of precipitated solids along the original flow channel. This study suggests MICP is a promising tool for enhancing wellbore cement integrity.
\end{abstract}

\section{Introduction}

According to the 2003 Oil Field Review report, since the earliest gas wells were drilled the escape of hydrocarbons to the surface has been a significant challenge. The gas migration can lead to sustained casing pressure (SCP) or sustained annular pressure (SAP) which indicates there is hydraulic communication between the formation and the annulus because of inadequate zonal isolation. The causes of SCP can be improper cement slurry design or damage to the primary cement after setting. According to the report, of the 15,500 producing, shut-in, or abandoned wells in the Gulf of Mexico, $43 \%$ of them have reported SCP and the problems only increase with the age of the well. Data from the United States Mineral Management Service cited in the report suggested that a 15 year old well has a $50 \%$ chance of a SCP problem (Brufatto et al., 2003).

\subsection{Wellbore cement integrity}

The primary purpose of wellbore cement is to provide zonal isolation critical for safe and effective operation of both production and 
injection wells. The presence of delaminations, apertures, fractures, voids and other unrestricted flow channels in the wellbore environment substantially reduces wellbore integrity. Compromised cement can cause lost zonal isolation leading to deleterious flow of fluids between zones or to the surface. Potential negative impacts of compromised wellbore cement include potential damage to drinking water aquifers, leakage of greenhouse gases (e.g. methane) to the atmosphere, reduction of sweep efficiency in enhanced oil recovery (EOR) operations, regulatory non-compliance, and failed mechanical integrity testing (MIT) necessary prior to plug-and-abandonment. Maintaining wellbore cement integrity is important to geothermal production, unconventional oil and gas, gas storage, or enhanced oil recovery wells (Choi et al., 2013; Crow et al., 2010; Gasda et al., 2004; Huerta et al., 2009; Newell and Carey, 2012).

\subsection{Alternative sealing technologies}

A common method for repairing wells with compromised integrity is the use of cement, in particular fine cement (Harris and Johnson, 1992; Lizak et al., 1992), that can be injected into gaps as small as $120 \mu \mathrm{m}$. The success rate of squeezing cement to fix leaks may be less than $50 \%$ due to the difficulties in getting cement to the proper locations (Bagal et al., 2016). Additional research is being performed to assess the use of gels, epoxies and nanocomposite materials that may be able to access smaller aperture fractures (Genedy et al., 2014; Todorovic et al., 2016). These novel materials may have additional considerations for use in repairing wells including 100 times higher viscosity than that of the MICP promoting sealing solutions. Higher viscosity fluids require increased pumping pressures to deliver the materials, potentially limiting the gap configurations that can be accessed. A comprehensive review of different methods to repair well integrity was not conducted, but a few options are compared in Table 1.

\subsection{Microbially induced calcite precipitation (MICP)}

While wellbore cements and ultrafine cements continue to be developed, there is an obvious need for novel technologies that can be delivered via low viscosity fluids thereby improving the ability to plug small aperture leaks such as fractures or delaminations at interfaces. MICP, as discussed in detail below, utilizes micrometer-sized organisms and low viscosity (aqueous) solutions thereby facilitating fluid transport into small aperture flow channels within cement. Data from mercury intrusion porosimetry performed on biomineralized sandstone cores suggested pore spaces in the size range of $6-16 \mu \mathrm{m}$ were most impacted by biomineralization treatment (Phillips, 2013). Conceivably, since the microbe itself is in the size range of $1-5 \mu \mathrm{m}$, the aperture of fractures that can be impacted by MICP treatment is only limited by the ability of the microbe to be transported into the fracture. These are smaller pore spaces than those accessible with cement-based technologies, which may be due to the higher viscosity of cement/water mixtures, compared to in biomineralization promoting solutions (Phillips et al., 2013b; Tamura et al., 1994). While the MICP treatment may have the advantage of sealing small aperture fractures and can be placed in channeled cement with water-based solutions, it is not without risk. For example, if fractures in the treatment zone extend to functional aquifers then there could be a risk of urea (a nitrogen source) impacting groundwater. This risk could be mitigated by carefully controlling the placement of the fluids, for example, only adding the volume estimated in the wellbore cement channeled region. In addition, the risk of injecting microbes can be mitigated by using different sources of the enzyme. Some additional sources include inactivated microbes, which contain active enzymes in their cells, using enzymes directly (from plant-based sources or extracted from microbial cells), or by promoting the entombment of the microbes at the end of the MICP sealing process, which would result in trapping of the microbes, reduced microbial transport, and likely inactivation over time (Phillips et al., 2013a,b).

\subsection{MICP fundamentals}

A commonly researched method to promote calcium carbonate precipitation uses the microbially produced enzyme, urease, to catalyze the hydrolysis of urea to change saturation conditions. In the presence of sufficient calcium, precipitation of calcium carbonate (MICP) results. The urease enzyme can be found in a wide variety of microorganisms (Mobley and Hausinger, 1989). Ureolysis-driven microbially-induced calcium carbonate $\left(\mathrm{CaCO}_{3}\right)$ precipitation (UICP) has been researched for a wide range of engineered applications (Phillips et al., 2013a) including amending or improving construction materials (De Belie and Verstraete, 2012; De Muynck et al., 2010; Dhami et al., 2012), cementing porous media (Al Qabany et al., 2011; DeJong et al., 2010; Tobler et al., 2012; van Paassen et al., 2010; Whiffin et al., 2007), and environmental remediation (Dupraz et al., 2009; Fujita et al., 2004; Hammes et al., 2003; Lauchnor et al., 2013; Mitchell et al., 2010; Okwadha and Li, 2011). In the presence of sufficient carbonate, calcium ions, and nucleation sites, calcium carbonate precipitation is promoted, often in the stable mineral form of calcite (Hammes and Verstraete, 2002; Stocks-Fischer et al., 1999) (Equation (1)).

$\left(\mathrm{NH}_{2}\right)_{2} \mathrm{CO}+2 \mathrm{H}_{2} \mathrm{O}+\mathrm{Ca}^{2+} \rightarrow 2 \mathrm{NH}_{4}^{+}+\mathrm{CaCO}_{3}$

While many studies related to MICP have been reported on a laboratory scale only a few have been performed on a field scale. These studies include the use of MICP to promote urea hydrolysis and calcite precipitation in groundwater (Fujita et al., 2008), improving the geotechnical quality of soils (Gomez et al., 2015; van Paassen et al., 2010) and promote fracture sealing $25 \mathrm{~m}$ below ground surface in the fractured dacite (Cuthbert et al., 2013). Recently, we described a study where MICP was used to seal a hydraulic fracture in a sandstone formation $340 \mathrm{~m}$ below ground surface (Phillips et al., 2016). The MICP study described here utilized Sporosarcina pasteurii, ATCC 11859, formerly Bacillus pasteurii (Yoon et al., 2001).

\section{Materials and methods}

\subsection{Site characterization}

The MICP sealing field demonstration was performed inside a $24.4 \mathrm{~cm}$ (9.625 inch) diameter well located on the William Crawford Gorgas Electric Generating Plant (Alabama Power, Southern Company) near Jasper, Alabama, USA hereafter referred to as "Gorgas". This well was drilled as part of the Department of Energy effort to characterize

Table 1

Emerging Technologies used to Repair Leaking Oil \& Gas Wells.

\begin{tabular}{|c|c|c|c|c|}
\hline Technology & Maturity & Smallest fracture penetrated & Initial Viscosity & References \\
\hline Micro-cements & Field utilization & $120-150 \mu \mathrm{m}$ & $250 \mathrm{cP}$ & Stormont, 2016 \\
\hline Ultrafine cementitious grout & Some field data & $150 \mu \mathrm{m}$ & $16-40 \mathrm{cP}$ & Product Data Sheets \\
\hline Gels and epoxies & Research \& development and some field data & $5-50 \mu \mathrm{m}$ & $\begin{array}{l}80-500 \mathrm{cP} \\
\text { Depends on temperature }\end{array}$ & Jones et al., 2014; Product Data Sheets \\
\hline Nanocomposite Materials & Research & $<1 \mu \mathrm{m}-13 \mu \mathrm{m}$ & $200 \mathrm{cp}$ & Stormont 2016 \\
\hline MICP & Research and field demonstration & $2-5 \mu \mathrm{m}$ & $1-3 \mathrm{cP}$ & Phillips, 2013 \\
\hline
\end{tabular}




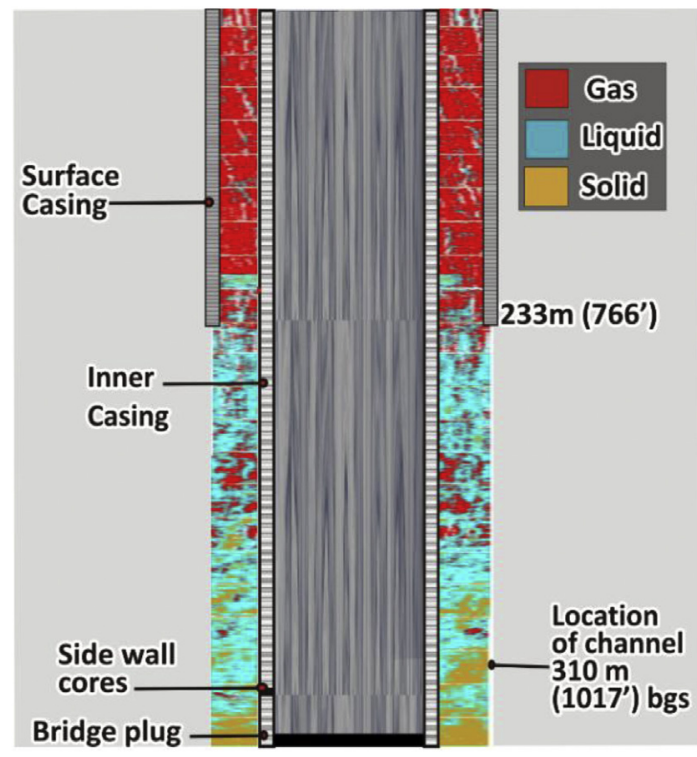

Fig. 1. This ultra-sonic cement imaging log suggests that the region near $310.0 \mathrm{~m}$ (1017 feet) bgs was favorable for an MICP sealing demonstration as a channel was shown to exist in the cement behind the casing. In this figure, the behind-the-casing environment of the wellbore is color coded by the fluid or solid detected. Red $=$ gas, blue $=$ liquid and $\tan =$ solid. In the region of $310 \mathrm{~m}$ below ground, both solids and liquids were detected with channels present. The sidewall cores obtained were located at 310.0, 310.3, and $310.9 \mathrm{~m}(1017,1018$ and 1020 feet) bgs. (For interpretation of the references to color in this figure legend, the reader is referred to the Web version of this article.)

geologic formations suitable for carbon sequestration. The well was used in a previous MICP experiment located at $340 \mathrm{~m}$ below the ground surface which focused on sealing a hydraulic fracture in a sandstone formation. This well has been used for testing purposes and could be described as shut in with plans to plug and abandon the well as soon as the testing projects are completed. Additional details of the well and site can be found in Phillips et al. (2016). The target zone for our current field study was at a depth where the wellbore cement was channeled approximately $310 \mathrm{~m}$ below ground surface.

\subsection{Cement evaluation $\log$ and sidewall coring}

The region of compromised cement was identified through the use of an ultrasonic imaging tool (USIT) provided by Schlumberger. The USIT, which was lowered into the well on a wireline, provided a continuous image of the quality of the cement bond at the cement-casing interface. Ultrasonic cement imaging $\log$ (IBC ${ }^{\circledast}$ Schlumberger) results, shown in Fig. 1, suggested that cement in the vicinity of $310 \mathrm{~m} \mathrm{(1017}$ feet) bgs appeared to contain solids but was dominated by a liquid filled channel above which very few solids were present.

To access this zone, three side wall cores were drilled at elevations 310.0, 310.3, and $310.9 \mathrm{~m}$ (1017, 1018 and 1020 feet) bgs. The coring device was lowered via wireline to the elevation chosen for coring then activated. Fig. 2a shows that the sidewall core recovered from $310.0 \mathrm{bgs}$ consisted of steel casing and good quality cement. The fracture transecting the core could possibly serve as a channel for flow of injected fluids. However, this cannot be confirmed as the fracture could have also occurred during the drilling of the core. This core sample did not extend into the surrounding shale formation. Fig. $2 \mathrm{~b}$ shows the core recovered from the elevation $310.3 \mathrm{~m}$ (1018 feet) bgs. This core consisted of steel casing, good quality cement, and dense black shale. A third core (not shown), drilled at elevation $310.9 \mathrm{~m}$ (1020 feet) bgs, penetrated the steel casing into a region devoid of cement, and no cement or shale was recovered. It was assumed that this core accessed the channel and was the target for subsequent MICP sealing.

\subsection{MICP field demonstration design}

The objective of the MICP field experiment was to demonstrate that MICP treatment can improve the integrity of compromised wellbore cement along the target elevation interval. The experimental procedure included: 1) creation of an access point through the casing to deliver fluids, 2) injection of microbial suspensions that attach to surfaces of the channel casing and cement interface, 3) injection of calcium-containing solutions that promote mineralization, and 4) assessing the degree of cement channel plugging by monitoring the relationship between injection flow rate and pressure. Conceptually the MICP seal grows in-situ from the surfaces of the cement and casing interfaces into the cement channel(s) until fluids can no longer be injected without exceeding the threshold fracture pressure of the surrounding formation (Fig. 3).

Collaborators on this field test included the Center for Biofilm Engineering at Montana State University (CBE/MSU), Southern Company (SC), Schlumberger Carbon Services (SLB), Loudon Technical Services (LTS), and Montana Emergent Technologies (MET). CBE/MSU together with MET designed the field test protocol, oversaw testing and analyzed results. SC provided access to the well and coordinated field operations with SLB, MET, and LTS. MET and LTS provided field oversight, coordinated equipment and subcontractors for the field work, and helped with the analysis of the results. All collaborators actively participated in decision-making and evaluation for each stage of the project. CBE/MSU, MET, LTS, and SLB moved on-site, received rental equipment and chemicals, and began cultivating microbes. Pumps, surface tubing, sampling equipment, mobile chemical testing laboratory, and the microbial laboratory were all set up as SLB mobilized equipment including the slickline unit and workover rig and crew. This project integrated expertise from practitioners (SC, SLB, and Shell) with experimental research and development (MSU/CBE, MET) to successfully complete the demonstration and thoroughly evaluate the field injection protocol, field delivery system, and effectiveness of the biomineralization sealing process.

\subsubsection{Preparation of microbes}

Filtered $(0.2 \mu \mathrm{m}$ bottle top filter Fisher Scientific, NJ, USA) BHI + Urea medium (37 g/L BHI Becton Dickinson, 20 g/L Urea, Fisher Scientific) was prepared in $250 \mathrm{ml}$ plastic screw top flasks and inoculated with a thawed glycerol stock suspension containing S. pasteurii. The cultures were grown overnight and then transferred to carboys (Reliance Products) containing $15 \mathrm{~L}$ YE-medium (5 g/L Yeast Extract, Sigma Aldrich, $20 \mathrm{~g} / \mathrm{L}$ urea, Potash Corp., $1 \mathrm{~g} / \mathrm{L} \mathrm{NH}{ }_{4} \mathrm{Cl}$, BASF) for an additional overnight growth period prior to injection amendment of the subsurface. The entire carboy was placed on a magnetic stir plate in a heated $\left(23^{\circ} \mathrm{C}\right)$ Rubbermaid tub, and the culture was allowed to grow for approximately $24 \mathrm{~h}$. No significant efforts were made to perform the carboy culturing aseptically in order to simulate a more realistic commercial application with typical oil field conditions. Overnight cultures of $S$. pasteurii were maintained throughout the demonstration. Periodic samples of the $S$. pasteurii inoculum were collected and monitored for cell concentration and purity by performing the drop plate method population assay on BHI + Urea agar plates (Herigstad et al., 2001). Cultures were started and transferred daily so that several $15 \mathrm{~L}$ (four gallon) carboys with at least $24 \mathrm{~h}$ old cultures were available for inoculation each day of the experiment. The suspension had an average culturable cell concentration of $3.5 \times 10^{6} \mathrm{cfu}$ / $\mathrm{ml}$ at the time of injection.

\subsubsection{Calcium-containing solution}

The concentrated mineralization media consisted of $9 \mathrm{~g} / \mathrm{L}$ yeast extract (Acros Organics, New Jersey, USA), $124 \mathrm{~g} / \mathrm{L}$ as $\mathrm{Ca}^{2+}$ (Ice Melt, Occidental Chemical Corporation, Texas, USA) and $72 \mathrm{~g} / \mathrm{L}$ urea (Potash Corporation, Illinois, USA). This solution provides the urea and calcium for biomineralization and precipitation to occur and was described as 

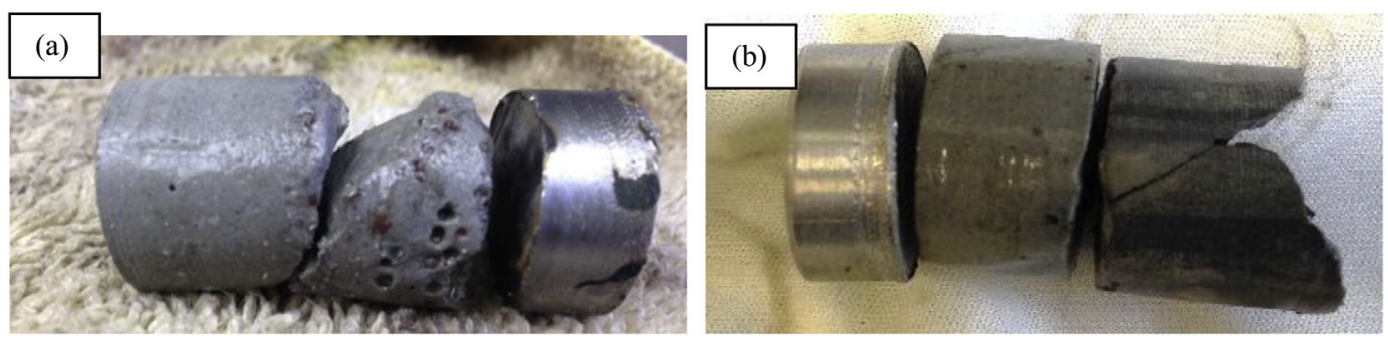

Fig. 2. December 2015 (a) Sidewall core consisting of steel casing and fractured, good quality cement recovered from elevation $310.0 \mathrm{~m}$ (1017 feet) bgs. (b) Sidewall core, consisting of steel casing, cement, and dense shale recovered from elevation $310.3 \mathrm{~m}$ (1018 feet) bgs. A third coring at elevation $3120.9 \mathrm{~m}$ ( $1020 \mathrm{feet}) \mathrm{bgs}$ exposed a void in the cement behind the casing. No cement or shale was recovered.

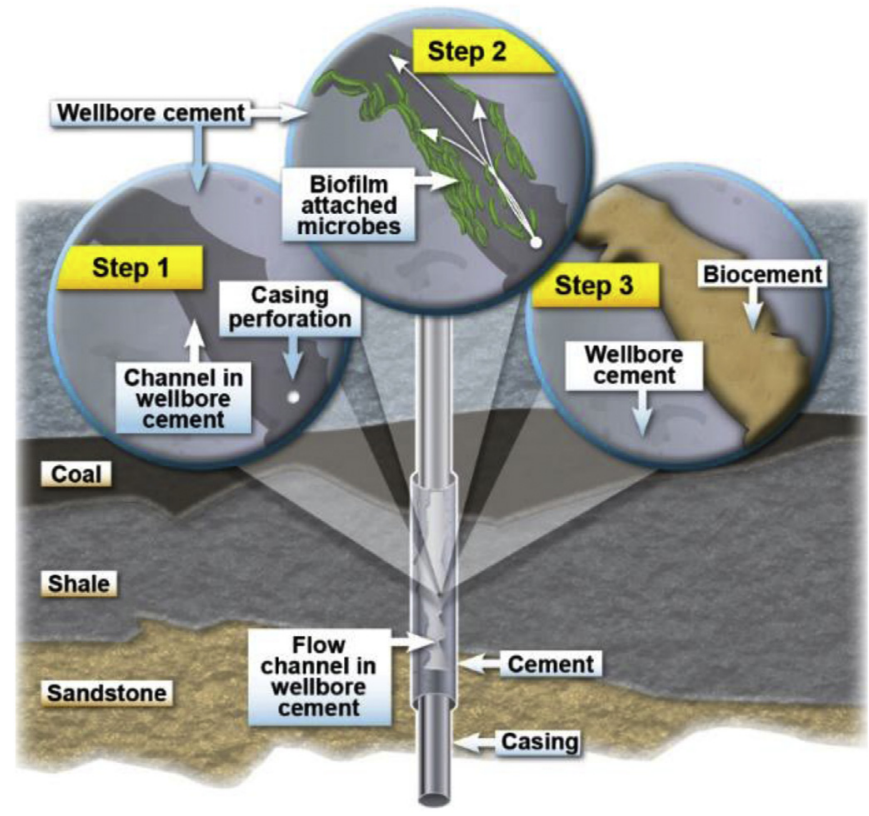

Fig. 3. Biomineralization promoting fluids are injected into the channel where a mineral seal forms to limit further fluid injection.

$\mathrm{YE}+$.

\subsection{Injection strategy}

The fracture was inoculated by injecting 3.0 gallons of overnight grown inoculum (amended with $5 \mathrm{~g} / \mathrm{L} \mathrm{YE}$ and $24 \mathrm{~g} / \mathrm{L}$ urea) through the slickline bailer followed by approximately five gallons of fresh water (amended with $24 \mathrm{~g} / \mathrm{L} \mathrm{NaCl}$ ). Each bailer of inoculum or concentrated growth/calcium solution was sampled and the $\mathrm{pH}$, conductivity, and urea concentrations were assessed (data not shown). A bailer on a slickline was used to deliver concentrated solutions and bacterial suspensions to the subsurface. The tubing string ran to the surface and was used to deliver brine to dilute concentrated bailer contents and deliver them into the fracture. A pulsed injection strategy was used to inject multiple microbial suspensions and calcium containing solutions over the course of four days (Appendix A Table 1) (Ebigbo et al., 2012; Phillips et al., 2016).

\section{Results and discussion}

\subsection{Initial pressure-flow test results}

A packer-bridge plug system was installed to isolate the region above and below the location of the three side wall cores. Water was pumped through the sidewall core holes to establish the relationship between pressure and injection flow rate. The flow rate was chosen to be $1.89-2.6 \mathrm{~L} / \mathrm{min}(0.5-0.7 \mathrm{gpm}$ which was chosen to maintain an injection pressure below the formation fracture threshold pressure, which was estimated to be approximately $81.6 \mathrm{~atm}$ (1200 psi). Pressure and flow rates were recorded as a total of $469 \mathrm{~L}$ (124 gallons) of water was injected. The water was trucked from the plant to two $2082 \mathrm{~L}$ ( 500 gallon) holding tanks where it was amended with $\mathrm{NaCl}$ (Mix-NFine, Cargill, Minnesota, USA) to $2.4 \%$ final $\mathrm{NaCl}$ concentration (hereafter referred to as the brine). As previously described (Phillips et al., 2016), the flow rate from the Cat Model 310 (Cat Pumps, Minneapolis, MN) injection pump powered by a $5 \mathrm{HP} 230 \mathrm{~V}$ motor with a variable speed drive was monitored by a Hoffer flow meter (Hoffer Inc., North Carolina, USA) with an Omega (Omega Engineering Inc., Connecticut, USA) pressure data logger to record surface pressure. The injection pump was connected to the tubing string to be able to pump brine into the subsurface.

Observations from the initial pressure-flow test suggest that the constant flow rates (first $1.89 \mathrm{~L} / \mathrm{min}$ then $2.64 \mathrm{~L} / \mathrm{min}(0.5 \mathrm{gpm}$ then 0.7 $\mathrm{gpm})$ ) resulted in several episodes of pressure first increasing to a maximum of $78.43 \mathrm{~atm}$ (1153 psi), then decreasing to approximately $59.9 \mathrm{~atm}(880 \mathrm{psi})$. This behavior suggests that the injection at these pressures may have opened up flow channels which were more connected (and possibly wider) than the flow paths (channels) initially present. A total of $469 \mathrm{~L}$ (124 gallons) of brine was injected at $2.64 \mathrm{~L} /$ $\min (0.7 \mathrm{gpm})$ (177 $\mathrm{min}$ in duration), providing indication that the planned injection of MICP fluids to achieve cement sealing could be accomplished with the maximum injection pressure remaining below the assumed formation fracture threshold pressure of approximately $81.6 \mathrm{~atm}$ (1200 psi).

The results from the pressure-flow test were analyzed assuming that most, if not all, of the injected flow passed through a single flow channel through the wellbore cement. Based on this "single channel" assumption it was possible to estimate the equivalent channel aperture width using Cubic's law (Equation (2)).

$Q=\frac{w \rho g b^{3}}{12 \mu} \frac{\triangle h}{L}$

where $\mathrm{Q}$ is the flow rate, $\mathrm{w}$ is the width of the channel, $\rho$ is the density of the fluid, $g$ is the gravitational constant, $b$ is the aperture of the channel gap, $\Delta \mathrm{h}$ is the measured injection pressure, $\mu$ is the dynamic viscosity of the fluid, and $\mathrm{L}$ is the length of the channel (assessed from the cement bond $\log$ to be approximately 30 feet) (Ranjith and Viete, 2011; Witherspoon et al., 1980). Using the pressure/flow analysis with Cubic's law we estimated a fracture aperture of $125 \mu \mathrm{m}$. This calculation assumes a single flow channel of width (w) equal to $40 \%$ of the circumference of the well casing or $0.31 \mathrm{~m}$ (1.02 feet), and a length $\mathrm{L}$ of $9.14 \mathrm{~m}$ (30 feet). Given the size of the estimated aperture, this gap may be difficult to seal with micro-cements in a squeeze job (Table 1) and was thus considered an appropriate test condition for the MICP treatment technology. 


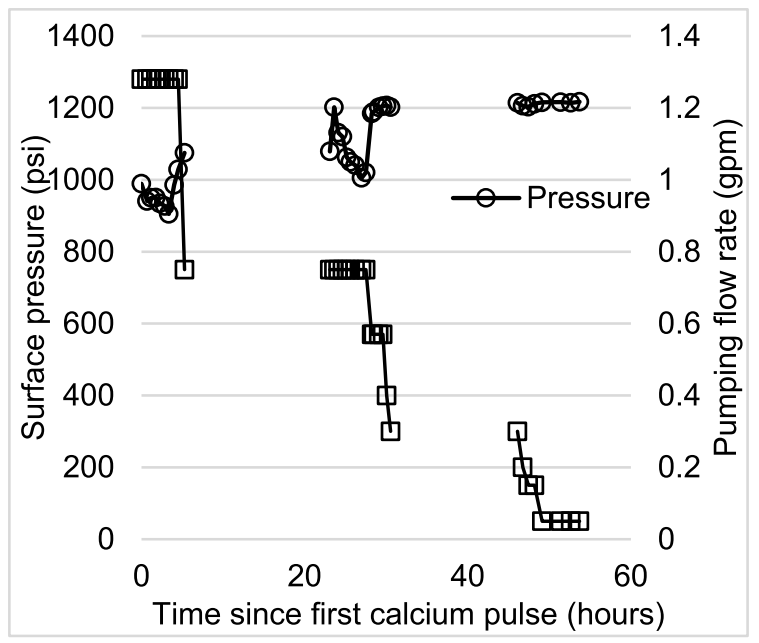

Fig. 4. Pressure increase corresponding to (decreasing) injection flow rate over time during the MICP sealing demonstration. Injections were terminated when the injection pressure reached 81.6 bar (1200 psi), which was estimated to be the fracture initiation pressure for the shale formation. The corresponding injection flow rate was less than $0.011 \mathrm{~m}^{3} / \mathrm{h}(0.05 \mathrm{gpm})$.

\subsection{MICP treatment results}

The channel treatment experiment was performed over the course of four days during which biomineralization fluids were delivered to the target interval. Three major results were observed over the course of the experiment: 1 ) injectivity was reduced, 2) the pressure falloff after shut in decreased and 3) a significant increase was observed in the percentage of solids in the channel after MICP treatment.

\subsubsection{Injectivity}

Injectivity of the fluid was significantly reduced from 0.29 cubic meters per hour $\left(\mathrm{m}^{3} / \mathrm{h}\right)(1.28 \mathrm{gpm})$ to less than $0.011 \mathrm{~m}^{3} / \mathrm{h}(0.05 \mathrm{gpm})$ after MICP treatment (Fig. 4). The flow rate was decreased as pressure increased to remain below a maximum pressure of 81.6 bar (1200 psi), which was deemed to possibly initiate a fracture in the shale formation, which was dominant in this interval. The reduction in injectivity was attributed to the sealing of the channel which was observed in the cement bond log discussed in section 3.2.3.

\subsubsection{Pressure falloff}

Mechanical integrity tests are used to determine whether there is a leak in the well's casing or tubing or whether there may be channels in the near wellbore environment. A well has mechanical integrity if: (1) there is no significant leak in the casing, tubing, or packer (internal mechanical integrity) and (2) there is no significant fluid movement through channels adjacent to an injection wellbore (external mechanical integrity) (Koplos et al., 2006). A series of pressure fall-off tests were performed on the final day after MICP treatment in the Gorgas well. Prior to the MICP treatment, pressure falloff was as high as $42 \%$ of the pressure decaying within $10 \mathrm{~min}$ after shut-in at 63.4 bar (920 psi). After MICP treatment on the final day of the experiment, the well was pressurized to $20.4,34.0$, and 82.7 bar $(300,500$, and 1200psi) and the percentage of pressure decay after $15 \mathrm{~min}$ was recorded. At $20.4 \mathrm{bar}$ (300 psi) a $5.1 \%$ pressure decay, at 34.0 bar ( $500 \mathrm{psi}$ ) a pressure decay of $7.1 \%$ and at 82.7 bar an $18 \%$ decay was observed after the $15-\mathrm{min}$ time interval. The treatment of the channel returned the well to a condition where it met the Colorado definition of a mechanical integrity for shut-in wells (the Gorgas well could be considered a shut in well) (Table 2). While this well is not in Colorado, the mechanical integrity test was only monitored for $15 \mathrm{~min}$ and not $30 \mathrm{~min}$. Thus, it could not be determined whether the well would meet the definition of mechanical integrity for injection wells in Alabama. The definition of mechanical integrity is different between states and the type of well and while this is not a comprehensive list of all regulations, a few examples are noted (Table 2).

\subsubsection{Solids increase}

Wellbore cement quality in the region of interest was examined using an ultrasonic imaging tool (USIT) (Schlumberger). Briefly, the USIT uses a transducer mounted to the bottom of the tool that detects ultrasonic waves reflected from the casing interfaces. The tool has a transmitter that emits ultrasonic pulses and the rate of decay of the waves gives an indication of the cement bond at the casing interface. The transducer is mounted on a rotating stage at the bottom of the tool so $360^{\circ}$ scanning can occur (Schlumberger, 2004).

The USIT was used before and after MICP treatment to characterize the cement quality. Before sealing occurred there appeared to be an approximately $40 \%$ lack of bonded cement in the annular space (Fig. 5a). The conceptual model is that there was likely a channel formed on the thin side of the annulus. This is also corroborated by the casing is not centered in the borehole at this depth in the well (data not shown). When the casing is not centralized it may be difficult for cement flow to reach the narrow side of the annular space resulting in a channel void of cement in that region.

The ultrasonic imaging tool (USIT) logs before and after MICP treatment indicated a significant increase in the solids content in the compromised cement region (Fig. 5b and c). These cement evaluation logs revealed a general narrowing of the channel observed in the cement casing interface with complete sealing observed in the region around $302 \mathrm{~m}$ (990 feet) bgs.

\section{Conclusions}

The three lines of evidence (reduced injectivity, reduced pressure fall-off and increased solids content) offer compelling evidence that the MICP sealing field demonstration at Gorgas was successful. MICP treatment resulted in significantly reduced injectivity which corresponded to substantial deposition of precipitated solids along the originally detected flow channel and a significant reduction in pressure fall-off after the well was shut in. As the MICP treatment technology moves toward commercial application, additional research and development will be performed to further improve methods of fluid delivery and increase the depth and temperature range where the treatment can be applied. In addition, other applications of MICP in the subsurface are currently being explored including permeability modification for enhanced resource recovery or application in fractured wells to seal existing fractures with subsequent re-fracturing to access new formation materials to recover additional resources (Cunningham et al., 2017).

\section{Nomenclature \\ Q flow rate \\ W width of the channel \\ $\mathrm{P} \quad$ density of the fluid \\ G gravitational constant \\ B aperture of the channel gap \\ $\Delta \mathrm{h} \quad$ injection pressure \\ L length of the channel}

\section{Acknowledgements}

This material is based upon work supported by the Department of Energy under Grant No. DE-FE0024296. Any opinions, findings, conclusions or recommendations expressed herein are those of the authors and do not necessarily reflect the views of the Department of Energy (DOE). The authors thank Laura Dobeck, Abby Thane, and Drew Norton at the Center for Biofilm Engineering. 
Table 2

Definitions of mechanical integrity for different well types.

\begin{tabular}{|c|c|c|c|c|}
\hline Location or Regulatory Responsibility & Pressure (psi) & Percentage Falloff & Duration (min) & Well type \\
\hline EPA & $>300$ & $3 \%$ & 30 & Injection (Environmental Protection Agency, 2008) \\
\hline Colorado & $>300$ & $10 \%$ & 15 & Injection, Shut-In (Colorado Oil and Gas Conservation Commission) \\
\hline Montana & $>300$ & $5 \%$ & 15 & Injection/Disposal (Montana Board of Oil and Gas Commission) \\
\hline Alabama & $<1500$ & $10 \%$ & 30 & Injection/Disposal (State Board of Oil and Gas of Alabama) \\
\hline Texas & $>200$ & $10 \%$ & 30 & Injection/Disposal (Texas Railroad Commission) \\
\hline
\end{tabular}

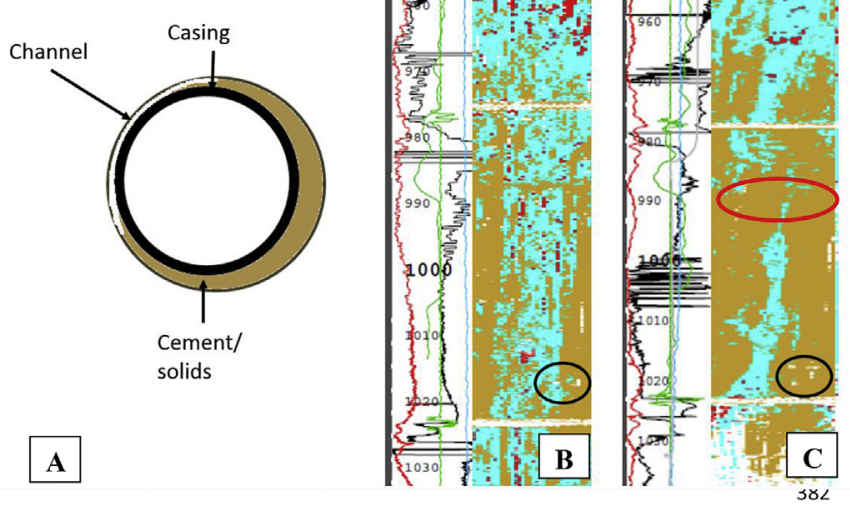

Fig. 5. (A), (B), and (C). The cement bond log scanned with the Schlumberger USIT from 292.60 to $316.98 \mathrm{~m}$ (m) (960-1040 feet) below ground surface. (A) Shows the likely plan view configuration of the original flow channel at the 310.0-310.6 m (1017-1019) foot elevation prior to MICP sealing. The casing in this depth in the borehole is not centered meaning that there could be a narrow side in the annular space, which was not completely filled with cement leaving a void. It was approximated that there could have been a gap that comprised $40 \%$ of the circumference of the casing. Panel (B) shows the cement bond log prior to MICP injection but after the side wall cores had been drilled at 310.0, 310.27, $310.6 \mathrm{~m}$ (m) (1017, 1018, 1019 feet) bgs (white circles inside black ovals indicate location of core points). Panel (C) shows the cement bond log scanned after MICP treatment. Red = gas, blue = liquid, $\tan =$ solids detected in the near wellbore environment between the casing and the formation. MICP sealing resulted in a substantial increase in solid material in the $9.1 \mathrm{~m}$ (30 foot) interval above the side wall core injection points. Note that at an elevation of about $301.75 \mathrm{~m}$ ( $990 \mathrm{ft}$ bgs, red circle) the solid material appears to completely surround the casing without visible voids. (For interpretation of the references to color in this figure legend, the reader is referred to the Web version of this article.)

\section{Appendix}

Table 1

Summary of injected fluids.

\begin{tabular}{|c|c|c|c|}
\hline 4/12/16 5:48 PM & Inoculum & $11.36(3)$ & $24.2(6.4)$ \\
\hline 4/12/16 6:16 PM & Inoculum & $8.52(2.25)$ & $23.1(6.1)$ \\
\hline 4/13/16 11:03 AM & $\mathrm{YE}+$ & $8.52(2.25)$ & $19.3(5.1)$ \\
\hline 4/13/16 11:45 AM & $\mathrm{YE}+$ & $8.52(2.25)$ & $18.9(5)$ \\
\hline 4/13/16 12:14 PM & $\mathrm{YE}+$ & $8.52(2.25)$ & $18.9(5)$ \\
\hline 4/13/16 1:55 PM & $\mathrm{YE}+$ & $8.52(2.25)$ & $19.3(5.1)$ \\
\hline 4/13/16 2:24 PM & $\mathrm{YE}+$ & $8.52(2.25)$ & $18.9(5)$ \\
\hline 4/13/16 3:04 PM & Inoculum & $8.52(2.25)$ & $18.9(5)$ \\
\hline 4/13/16 3:34 PM & Inoculum & $8.52(2.25)$ & $19.7(5.2)$ \\
\hline 4/13/16 4:02 PM & Inoculum & $8.52(2.25)$ & $18.9(5)$ \\
\hline
\end{tabular}




\begin{tabular}{|c|c|c|c|}
\hline Date + time & Bailer Contents & Delivered Vol of Bailer L (Gal) & Delivered Vol of Brine L (Gal) \\
\hline 4/14/16 10:09 AM & $\mathrm{YE}+$ & $8.52(2.25)$ & $18.9(5)$ \\
\hline 4/14/16 10:40 AM & $\mathrm{YE}+$ & $8.52(2.25)$ & $18.9(5)$ \\
\hline 4/14/16 11:42 AM & $\mathrm{YE}+$ & $8.52(2.25)$ & $18.9(5)$ \\
\hline 4/14/16 12:13 PM & $\mathrm{YE}+$ & $8.52(2.25)$ & $18.9(5)$ \\
\hline 4/14/16 12:45 PM & $\mathrm{YE}+$ & $8.52(2.25)$ & $18.9(5)$ \\
\hline 4/14/16 2:34 PM & Inoculum & $8.52(2.25)$ & $18.9(5)$ \\
\hline 4/14/16 3:07 PM & $\mathrm{YE}+$ & $8.52(2.25)$ & $36.3(9.6)$ \\
\hline 4/14/16 3:29 PM & $\mathrm{YE}+$ & $8.52(2.25)$ & $18.9(5)$ \\
\hline 4/14/16 4:10 PM & $\mathrm{YE}+$ & $8.52(2.25)$ & $18.9(5)$ \\
\hline 4/14/16 4:39 PM & $\mathrm{YE}+$ & $8.52(2.25)$ & $18.9(5)$ \\
\hline 4/14/16 5:07 PM & Inoculum & $8.52(2.25)$ & $17.4(4.6)$ \\
\hline 4/15/16 11:14 AM & $\mathrm{YE}+$ & $8.52(2.25)$ & $18.9(5)$ \\
\hline $4 / 15 / 1611: 59 \mathrm{AM}$ & $\mathrm{YE}+$ & $8.52(2.25)$ & $19.3(5.1)$ \\
\hline 4/15/16 1:17 PM & $\mathrm{YE}+$ & $8.52(2.25)$ & $18.9(5)$ \\
\hline 4/15/16 4:08 PM & YE + & $8.52(2.25)$ & 18.9 (5) \\
\hline
\end{tabular}

\section{References}

Al Qabany, A., Soga, K., Santamarina, C., 2011. Factors affecting efficiency of microbially induced calcite precipitation. J. Geotech. Geoenviron. Eng. 138, 992-1001.

Bagal, J., Onadeko, G., Hazel, P., Dagestad, V., 2016. Annular barrier as an alternative to squeezes in challenging wells: technology review and case histories. Society of Petroleum Engineers SPE/AAPG Africa Energy and Technology Conference, 5-7 December, Nairobi City, Kenya.

Brufatto, C., Cochran, J., Conn, L., Power, D., El-Zeghaty, S., Fraboulet, B., Griffin, T., James, S., Munk, T., Justus, F., Levine, J., Montgomery, C., Murphy, D., Pfeiffer, J., Pornpoch, T., Rishmani, L., 2003. From mud to cement- building gas wells. Oilfield Rev. 15, 62-76.

Choi, Y.-S., Young, D., Nešić, S., Gray, L.G.S., 2013. Wellbore integrity and corrosion of carbon steel in $\mathrm{CO}_{2}$ geologic storage environments: a literature review. International Journal of Greenhouse Gas Control 16, S70-S77.

Colorado Oil and Gas ConservationCommission, Operator Guidance, Rule 326: Mechanical Integrity Guidance http://cogcc.state.co.us/documents/reg/ OpGuidance/Rule\%20326\%20Mechanical\%20Integrity\%20-\%205-15-15.pdf.

Crow, W., Carey, J.W., Gasda, S., Brian Williams, D., Celia, M., 2010. Wellbore integrity analysis of a natural $\mathrm{CO}_{2}$ producer. International Journal of Greenhouse Gas Control 4, 186-197.

Cunningham, A., Geralch, R., Phillips, A., Hiebert, R., 2017. Methods for increased hydrocarbon recovery through mineralization sealing of hydraulically fractured rock followed by refracturing. Non-provisional US Patent 9 (739), 129 B2.

Cuthbert, M.O., McMillan, L.A., Handley-Sidhu, S., Riley, M.S., Tobler, D.J., Phoenix, V.R., 2013. A field and modeling study of fractured rock permeability reduction using microbially induced calcite precipitation. Environ. Sci. Technol. 47, 13637-13643.

De Belie, N., Verstraete, W., 2012. Diatomaceous earth as a protective vehicle for bacteria applied for self-healing concrete. J. Ind. Microbiol. Biotechnol. 39, 567-577.

De Muynck, W., De Belie, N., Verstraete, W., 2010. Microbial carbonate precipitation in construction materials: a review. Ecol. Eng. 36, 118-136.

DeJong, J.T., Mortensen, B.M., Martinez, B.C., Nelson, D.C., 2010. Bio-mediated soil improvement. Ecol. Eng. 36, 197-210.

Dhami, N.K., Reddy, M.S., Mukherjee, A., 2012. Improvement in strength properties of ash bricks by bacterial calcite. Ecol. Eng. 39, 31-35.

Dupraz, S., Parmentier, M., Menez, B., Guyot, F., 2009. Experimental and numerical modeling of bacterially induced $\mathrm{pH}$ increase and calcite precipitation in saline aquifers. Chem. Geol. 265, 44-53.

Ebigbo, A., Phillips, A., Gerlach, R., Helmig, R., Cunningham, A.B., Class, H., Spangler, L.H., 2012. Darcy-scale modeling of microbially induced carbonate mineral precipitation in sand columns. Water Resour. Res. 48, W07519.

Environmental Protection Agency, 2008. Determination of the Mechanical Integrity of Injection wells.

Fujita, Y., Redden, G.D., Ingram, J.C., Cortez, M.M., Ferris, F.G., Smith, R.W., 2004 Strontium incorporation into calcite generated by bacterial ureolysis. Geochem. Cosmochim. Acta 68, 3261.

Fujita, Y., Taylor, J., Gresham, T., Delwiche, M., Colwell, F., McLing, T., Petzke, L., Smith, R., 2008. Stimulation of microbial urea hydrolysis in groundwater to enhance calcite precipitation. Environ. Sci. Technol. 42, 3025-3032.

Gasda, S.E., Bachu, S., Celia, M.A., 2004. Spatial characterization of the location of potentially leaky wells penetrating a deep saline aquifer in a mature sedimentary basin. Environ. Geol. 46, 707-720.

Genedy, M., Stormont, J., Matteo, E., Taha, M.R., 2014. Examining epoxy-based nanocomposites in wellbore seal repair for effective $\mathrm{CO}_{2}$ sequestration. Energy Procedia 63, 5798-5807.

Gomez, M.G., Martinez, B.C., DeJong, J.T., Hunt, C.E., deVlaming, L.A., Major, D.W., Dworatzek, S.M., 2015. Field-scale bio-cementation tests to improve sands. Proceedings of the Institution of Civil Engineers - Ground Improvement 168, 206-216.

Hammes, F., Seka, A., Van Hege, K., Van de Wiele, T., Vanderdeelen, J., Siciliano, S., Verstraete, W., 2003. Calcium removal from industrial wastewater by bio-catalytic $\mathrm{CaCO}_{3}$ precipitation. J. Chem. Technol. Biotechnol. 78, 670-677.

Hammes, F., Verstraete, W., 2002. Key roles of pH and calcium metabolism in microbial carbonate precipitation. Rev. Environ. Sci. Biotechnol. 1, 3-7.

Harris, K., Johnson, B., 1992. Successful remedial operations using ultrafine cement. In: Society of Petroleum Engineers, Mid-continent Gas Symposium. Society of Petroleum Engineers, Amarillo, Texas, pp. 21-30.

Herigstad, B., Hamilton, M., Heersink, J., 2001. How to optimize the drop plate method for enumerating bacteria. J. Microbiol. Meth. 44, 121-129.

Huerta, N.J., Bryant, S.L., Strazisar, B.R., Kutchko, B.G., Conrad, L.C., 2009. The influence of confining stress and chemical alteration on conductive pathways within wellbore cement. Energy Procedia 1, 3571-3578.

Jones, R., Karcher, J.D., Ruch, A., Beamer, A., Smit, P., Hines, S., Olson, M.R., Day, D., 2014. Rigless Operations to Restore Wellbore Integrity Using Sythetic-based Resin Sealant. SPE/EAGE European Unconventional Resources Conference and Exhibition, Vienna, Austria February 2014.

Koplos, J., Kobelski, B., Karimjee, A., Sham, C., 2006. UIC Program- Mechanical Integrity Testing: Lessons for Carbon Capture and Storage? Fifth Annual Conference on Carbon Capture and Sequestration. DOE-National Energy Technology Laboratory, Virginia, USA.

Lauchnor, E.G., Schultz, L.N., Bugni, S., Mitchell, A.C., Cunningham, A.B., Gerlach, R., 2013. Bacterially induced calcium carbonate precipitation and strontium coprecipitation in a porous media flow system. Environ. Sci. Technol. 47, 1557-1564.

Lizak, K., Zeltmann, T., Crook, R., 1992. Permian basin operators seal casing leaks with small-particle cement. Society of petroleum engineers, permian basin oil and gas recovery conference. Midland, Texas, USA. Society of Petroleum Engineers 429-434.

Mitchell, A., Dideriksen, K., Spangler, L., Cunningham, A., Gerlach, R., 2010. Microbially enhanced carbon capture and storage by mineral-trapping and solubility-trapping. Environ. Sci. Technol. 5270-5276.

Mobley, H.L.T., Hausinger, R.P., 1989. Microbial ureases: significance, regulation, and molecular Characterization. Microbiol. Rev. 53, 85-108.

Montana Board of Oil and Gas Commission Underground Injection Control Rules. http:// bogc.dnrc.mt. gov/uicrules.asp.

Newell, D.L., Carey, J.W., 2012. Experimental evaluation of wellbore integrity along the cement-rock boundary. Environ. Sci. Technol. 47, 276-282.

Okwadha, G.D.O., Li, J., 2011. Biocontainment of polychlorinated biphenyls (PCBs) on flat concrete surfaces by microbial carbonate precipitation. J. Environ. Manag. 92, 
$2860-2864$.

Phillips, A., 2013. Biofilm-induced Calcium Carbonate Precipitation: Application in the Subsurface. Dissertation College of Engineering, Chemical and Biological Engineering. Montana State University, pp. 223.

Phillips, A.J., Cunningham, A.B., Gerlach, R., Hiebert, R., Hwang, C., Lomans, B.P., Westrich, J., Mantilla, C., Kirksey, J., Esposito, R., Spangler, L., 2016. Fracture sealing with microbially-induced calcium carbonate precipitation: a field study. Environ. Sci. Technol. 50, 4111-4117.

Phillips, A.J., Gerlach, R., Lauchnor, E., Mitchell, A.C., Cunningham, A.B., Spangler, L. 2013a. Engineered applications of ureolytic biomineralization: a review. Biofouling 29, 715-733.

Phillips, A.J., Lauchnor, E., Eldring, J., Esposito, R., Mitchell, A.C., Gerlach, R., Cunningham, A.B., Spangler, L.H., 2013b. Potential $\mathrm{CO}_{2}$ leakage reduction through biofilm-induced calcium carbonate precipitation. Environ. Sci. Technol. 47, 142-149.

Halliburton Product Data Sheet: H007588. (2014). MOC/OneTM Slurry for Selective Water Control Slurry Penetration Hydrocarbon-based Ultrafine Cement Slurry Nonreactive in Oil or Gas Zones, http://www.halliburton.com/public/pe/contents/ data_sheets/web/h/h07588.pdf.

US Grout Product Data Sheet: Ultrafine Standard(SD) Cementitious Grout Technical Data Sheet http://usgrout.com/PDFs/USGrout-UltrafineSD-DataSheet.pdf.

Cargill Resin Product Data Sheets https://www.cargill.com/bioindustrial/chemresepoxy-resins.

Ranjith, P.G., Viete, D.R., 2011. Applicability of the 'cubic law' for non-Darcian fracture flow. J. Petrol. Sci. Eng. 78, 321-327.

Schlumberger, 2004. USI UltraSonic Imager Tool. Schlumberger Marketing Communications, Houston. https://www.slb.com/ /media/Files/production/ product sheets/well integrity/usi.pdf.

State Oil and Gas Board of Alabama, David, E., Bolin, E., 2014. State Oil and Gas Board of Alabama Administrative Code Oil and Gas Report: the Gold Book. . http://www2. ogb.state.al.us/documents/misc ogb/goldbook.pdf.

Stormont, John, 2016. Wellbore Seal Repair Using Nanocomposite Materials. https://doi. org/10.2172/1337552. United States. https://www.osti.gov/servlets/purl/
1337552.

Stocks-Fischer, S., Galinat, J., Bang, S., 1999. Microbiological precipitation of $\mathrm{CaCO}_{3}$. Soil Biol. Biochem. 31, 1563-1571.

Tamura, M., Goto, T., Ogino, T., Shimizu, K., 1994. Injection with Ultra-fine Cement into fine Sand Layer. International Offshore and Polar Engineering Conference. International Society of Offshore and Polar Engineers, Osaka, Japan, pp. 567-571.

Texas Railroad Commission, 2015. Injection/disposal Well Permitting, Testing, and Monitoring Manual-summary of Testing Requirements. http://www.rrc.state.tx.us/ oil-gas/publications-and-notices/manuals/injectiondisposal-well-manual/pressuretest-report-summary-of-testing-requirements/test-evaluation/.

Tobler, D., Maclachlan, E., Phoenix, V., 2012. Microbially mediated plugging of porous media and the impact of differing injection strategies. Ecol. Eng. 42, 270-278.

Todorovic, J., Raphaug, M., Lindeberg, E., Vrålstad, T., Buddensiek, M.-L., 2016. Remediation of leakage through annular cement using a polymer resin: a laboratory study. Energy Procedia 86, 442-449.

van Paassen, L., Ghose, R., van der Linden, T., van der Star, W., van Loosdrecht, M., 2010. Quantifying biomediated ground improvement by ureolysis: large-scale biogrout experiment. J. Geotech. Geoenviron. Eng. 136, 1721-1728.

Whiffin, V., van Paassen, L., Harkes, M., 2007. Microbial carbonate precipitation as a soil improvement technique. Geomicrobiol. J. 24, 417-423.

Witherspoon, P.A., Wang, J.S.Y., Iwai, K., Gale, J.E., 1980. Validity of cubic law for fluid flow in a deformable rock fracture. Water Resour. Res. 16, 1016-1024.

Yoon, J.H., Lee, K.C., Weiss, N., Kho, Y.H., Kang, K.H., Park, Y.H., 2001. Sporosarcin aquimarina sp. nov., a bacterium isolated from seawater in Korea, and transfer of Bacillus globisporus (Larkin and Stokes 1967), Bacillus psychrophilus (Nakamura 1984) and Bacillus pasteurii (Chester 1898) to the genus Sporosarcina as Sporosarcina globispora comb. nov., Sporosarcina psychrophila comb. nov. and Sporosarcina pasteurii comb. nov., and emended description of the genus Sporosarcina. Int. J. Syst. Evol. Microbiol. 51, 1079-1086.Further reading

ControlSEAL ${ }^{\mathrm{TM}}$ An Engineered Resin Solution Product Data Sheet https://wildwell.com/ wp-content/uploads/WW-Flyer-ControlSEAL.w.pdf. 